\title{
Serum triiodothyronine determination in clinical use
}

\author{
J. E. H. STAFFORD ${ }^{1}$, S. LEES, AND D. WATSON \\ From the Area Laboratory, King Edward VII Hospital, Windsor
}

SYNOPSIS Two radioimmunoassays for the determination of serum triiodothyronine $\left(\mathrm{T}_{3}\right)$ weredeveloped. The assay of $T_{3}$ in unextracted serum had several advantages over the assay on ex- $\vec{\omega}$ tracted serum and was chosen for the routine determination of $T_{3}$ in serum from 117 patients re교응 quiring assessment of their thyroid status.

In 53 subjects considered retrospectively not to have thyroid dysfunction nor to have been on: steroid contraceptives or therapy, the pooled mean serum $T_{3}$ concentration was 1.92 (actual range ${ }^{V}$ $0 \cdot 88-2.62) \mathrm{nmol} / \mathrm{l}$. A significant inverse relationship was observed between the serum $\mathrm{T}_{3}$ level and $\hat{\mathrm{N}}$ the age of the subject. Serum total $T_{3}$ levels discriminate clearly between hypo-, eu- and hyper-윽 thyroid patients and provide a rather more sensitive index of hyperthyroid function than total serum$T_{4}$. In the face of normal serum $T_{4}$, the $T_{3}$ level was depressed in five patients with marked hypo-proteinaemia and elevated in two patients taking heroin.

The application of radioimmunological methods to the measurement of serum triiodothyronine $\left(T_{3}\right)$ in health and disease has revealed a previously unsuspected role for this hormone in the maintenance of the euthyroid state. Clinically, serum $\mathrm{T}_{3}$ estimations have been advocated for detecting early thyrotoxicosis (Hollander et al, 1971b) and have revealed a new variant of hyperthyroidism, ' $\mathrm{T}_{3}$-toxicosis', in which patients diagnosed unequivocally as thyrotoxicosis have normal serum thyroxine $\left(\mathrm{T}_{4}\right)$ levels but increased concentrations of $\mathbf{T}_{3}$ (Sterling $e t$ al, 1970). In addition it is now clear that treatment of hyperthyroidism, by surgery or with drugs, leads to preferential serum $\mathbf{T}_{3}$ production (Bellabarba and Tremblay, 1972) as do low iodine diets (Hollander et al, 1971a).

The accuracy of methods based on protein-binding techniques for $T_{3}$ analysis has been impaired by interference from in vivo $\mathrm{T}_{3}$-binding proteins, in particular thyroid hormone-binding globulin (TBG). When interference from this source has gone unrecognized high serum values for $T_{3}$ have been reported (Gharib et al, 1970).

Several reagents capable of blocking plasma protein $\mathbf{T}_{3}$-binding sites have been reported and these include $\mathrm{T}_{4}$ (Chopra et al, 1971), tetrachlorothyronine

'Present address: Pharmacological Biochemistry, G. D. Searle \& Co Ltd, Lane End Road, High Wycombe, Bucks HP12 4HL

Received for publication 25 November 1975
(Mitsuma et al, 1971), diphenylhydantoin (Lieblich and Utiger, 1972), salicylate (Larsen, 1971), and 8anilino-naphthalene-sulphonic acid (Mitsuma et al, ֶ 1972). Each has drawbacks; either they are unstable $\mathrm{Q}$ in solution or they interfere with the antigen-antibody reaction (Hüfner and Hesch, 1973a). Recentlyo sodium ethylmercurithiosalicylate (Merthiolate, $\underset{ }{\supset}$ thiomersal) has been shown to inhibit the binding of $\mathrm{T}_{3}$ to thyroxine-binding proteins (Bellabarba and: Tremblay, 1973), and this reagent has been in-o corporated into radioimmunoassays for triiodo- -0 thyronine (Hüfner and Hesch, 1973b; Kirkegaard et $a l, 1974)$. In the presence of serum proteinso merthiolate does not influence the antibody-hapten reaction (Kanagasabapathy and Wellby, 1974).

This report describes a comparison of two radioimmunoassays for serum $T_{3}$, the alcoholic extraction assay being used as a reference method for the assay on unextracted serum. Merthiolate was used ${ }^{\mathrm{N}}$ to block the TBG binding sites. A preliminary 0 clinical evaluation of the results on patients for N whom routine in vitro thyroid function tests haveo been requested is presented.

\section{Material and Methods}

BARBITONE-ALBUMIN-MERTHIOLATE BUFFER Barbitone buffer $(0.1 \mathrm{~mol} / 1)$ at $\mathrm{pH} 8.65$ contained Merthiolate (sodium ethylmercurithiosalicylate, 5.00 $\mathrm{mmol} / \mathrm{l})$ and bovine albumin $(5 \mathrm{~g} / 1)$. All solutions were stored at $4^{\circ} \mathrm{C}$ unless otherwise stated. 642 
LABELLED TRIIODOTHYRONINE

High specific activity 125I-L-triiodothyronine ( $c a$ $400 \mathrm{mCi} / \mathrm{mg}$ ) in $50 \%$ propylene glycol was purchased from Abbott Laboratories and further purification was found to be unnecessary. It was diluted to about $500 \mathrm{pmol} / \mathrm{l}$ with barbitone-albumin-Merthiolate buffer.

\section{STANDARDS}

L-3', 3, 5-triiodothyronine (B grade) was obtained from Calbiochem Ltd, and its molar extinction coefficient (Gemmill, 1955) in sodium hydroxide (40 $\mathrm{mmol} / \mathrm{l}$ ) was used as an index of purity. Further purification proved to be unnecessary. A stock standard solution $(768 \mu \mathrm{mol} / \mathrm{l})$ was prepared in acidified ethanol $(10 \mathrm{ml} \mathrm{HCl} / \mathrm{l})$ and stored at $-20^{\circ} \mathrm{C}$. Standard $T_{3}$ was prepared by diluting the stock standard solution 125 times with sodium hydroxide (40 mmol/l). A $50 \mu \mathrm{l}$ aliquot of this solution was diluted to $10 \mathrm{ml}$ with $\mathrm{T}_{3}$-free serum or with $67 \%$ ethanol, and these working standards were stored in small aliquots at $-20^{\circ} \mathrm{C}$.

Assay standards were prepared immediately before the assay by doubling dilutions of working standard in $\mathrm{T}_{3}$-free serum or $67 \%$ ethanol to give from 768 to $24 \mathrm{fmol}$ of $T_{3}$ per assay tube.

\section{TRIIODOTHYRONINE-FREE SERUM}

Five grams of Norit A charcoal (Sigma) were added to $50 \mathrm{ml}$ of pooled, human sera (visibly free from haemolysis and icterus) and gently stirred for one hour at room temperature. After centrifugation a further $4 \mathrm{~g}$ were added and the process was repeated. Finally the supernatant was passed through millipore filters (Sartorius Membrane filter SM $11306,0.45 \mu \mathrm{m})$ and stored at $-20^{\circ} \mathrm{C}$. More than $99 \%$ of added ${ }^{125} \mathrm{I}_{-} \mathrm{T}_{3}$ was removed by this procedure.

\section{ANTISERUM}

The antiserum (No. 5303), raised in sheep against a triiodothyronine-albumin conjugate, was kindly donated by Professor R. P. Ekins (Institute of Nuclear Medicine, The Middlesex Hospital, London). Small volumes were stored at $-20^{\circ} \mathrm{C}$, thawed when required, and diluted to 1:1400 with barbitone-albumin-Merthiolate buffer.

\section{CHARCOAL SUSPENSION}

For the assay of $T_{3}$ in unextracted serum an $8 \mathrm{~g} / 1$ suspension of Norit A charcoal in barbitone buffer was used. Assays carried out in $67 \%$ ethanol required the charcoal to be coated with Dextran $\mathrm{T}_{70}$ $(0.5 \mathrm{~g} / \mathrm{l})$ for the optimal separation of free and antibody-bound $\mathbf{T}_{\mathbf{3}}$.
PATIENTS AND PREPARATION OF SAMPLES

Thyroid function tests were requested on 117 patients seen by general practitioners. Blood was obtained by venepuncture from these outpatients and allowed to clot, and the serum was separated by centrifugation. The samples were stored at $-20^{\circ} \mathrm{C}$. In some experiments alcoholic extracts of serum were prepared by the addition of two volumes of ice-cold ethanol and spinning down the precipitated proteins. Recovery of added ${ }^{125} \mathrm{I}-\mathrm{T}_{3}$ under these conditions was $100 \%$ and confirms the results of Patel and Burger (1973). Duplicate $50 \mu 1$ aliquots of the supernatant were used directly in the radioimmunoassay.

Thyroxine was measured by the Abbot Tetrasorb procedure controlled as previously described (Watson and Lees, 1973). Sera showing $T_{4}$ levels that were close to upper or lower normal limits were assayed for 'free thyroxine index' (FTI). The latter was calculated as total $T_{4}$ divided by the unsaturated thyroid hormone-binding globulin level, expressed as a fraction of a laboratory pooled serum standard and measured by the Thyopac-3 test (Radiochemical Centre).

\section{Radioimmunoassay}

To $50 \mu \mathrm{l}$ of the unknowns, standards, and 'zero' standards were added $100 \mu \mathrm{l}$ of ${ }^{125} \mathrm{I}_{-} \mathrm{T}_{3}$ solution and $100 \mu \mathrm{l}$ of diluted antiserum. For the unknowns and 'zero' standard a similar set of tubes was set up containing buffer instead of antiserum (blanks). After mixing and incubation overnight at $4^{\circ} \mathrm{C}$ or for one hour at $37^{\circ} \mathrm{C}$, the tubes were equilibrated in an ice bath. A $500 \mu$ l aliquot of a well-stirred charcoal suspension at $2^{\circ} \mathrm{C}$ was forcibly added to each tube with the aid of an automatic syringe pipette. After incubation for 20 minutes the tubes were centrifuged at $4000 \mathrm{rev} / \mathrm{min}$ for 10 minutes and returned to the ice bath. The supernatants were removed by suction and the charcoal pellets counted in an LKB Wallac 8000 gamma counter for at least 60 seconds (ie, about $10^{4}$ counts).

\section{CALCULATIONS}

All counts were automatically corrected for background.

\section{Standards}

The reciprocal of $B$, the fraction of $T_{3}$ bound by the antibody, was calculated by the formula:

$$
\frac{1}{B}=\frac{F_{o}}{F_{o}-F_{u}}
$$

where $B$ is the fraction bound, $F_{o}$ is the number of counts adsorbed by the charcoal in the blank, ie, in the absence of antiserum, and $F_{u}$ is the number of 
counts adsorbed by the charcoal in each standard tube in the presence of antiserum. This was plotted against the amount of cold $\mathrm{T}_{3}$ in each standard tube, and a reproducible linear relationship was found over the range $0-768 \mathrm{fmol} T_{3}$, corresponding to serum concentrations from zero to about $15 \mathrm{nmol} / \mathrm{l}$.

\section{Unknowns}

Preliminary experiments indicated that the adsorption of free $T_{3}$ onto charcoal varied from serum to serum and it was found necessary to run a blank with each sample for accurate results. The reciprocal of the fraction bound was calculated as for the standards. The serum $T_{3}$ content was derived from the standard curve, corrected for any dilution and expressed as $\mathrm{nmol} / \mathrm{l}$.

\section{Statistics}

The mean, standard deviation, and correlation and regression coefficients were calculated according to Snedecor and Cochran (1956) on a programmable desk-top calculator.

\section{Results}

\section{SPECIFICITY}

Cross-reaction of the antisera with thyroxine $\left(\mathrm{T}_{4}\right)$, tetraiodothyroacetic acid, and triiodothyroacetic acid was less than $0.1 \%$ in each case. Doubling dilutions of the sera from thyrotoxic and euthyroid patients with $\mathbf{T}_{3}$-free serum resulted in curves that did not differ significantly from the standard curve.

\section{RECOVERY EXPERIMENTS}

Recovery was determined by comparing the amount of $\mathrm{T}_{3}$ detected by radioimmunoassay $(\mathrm{y})$ with the known quantities (up to $600 \mathrm{fmol} \mathrm{T}_{3}$ ) added to hypo-, eu-, and hyper-thyroid sera (x). For the assay on alcoholic extracts the relationship was given by the equation $\mathrm{y}=1.02 \mathrm{x}+4.72$ ( $\mathrm{x}$ and $\mathrm{y}$ units in fmol, $r=0.987, n=16$, and $P<0.001)$. For the unextracted serum assay the line was given by $\mathrm{y}=$ $1.02 \mathrm{x}-1.08(\mathrm{r}=0.980, \mathrm{n}=28, \mathrm{P}<0.001)$. When the same sample was analysed by both methods the amount found in the unextracted serum (y) was highly correlated with the level detected by the alcoholic extraction assay (x) and the relationship was described by the equation $y=1.05 x-0.02$ $(\mathrm{r}=0.973, \mathrm{n}=31, \mathrm{P}<0.001)$. The result confirms the ability of Merthiolate to block the $\mathrm{T}_{3}$-binding sites of serum thyroxine-binding globulin. The incubation time could be reduced to one hour at $37^{\circ} \mathrm{C}$ without loss of accuracy or sensitivity. The estimate at $37^{\circ} \mathrm{C}(\mathrm{y})$ was related to the value at $4^{\circ} \mathrm{C}(\mathrm{x})$ by the equation $\mathrm{y}=1.02 \mathrm{x}+0.03(\mathrm{r}=0.984, \mathrm{n}=18, \mathrm{P}<$ 0.001 ).

\section{SENSITIVITY AND REPRODUCIBILITY}

For the assay on unextracted serum samples these $\bar{C}$ statistics have been summarized in table I. The between-batch coefficient of variation for six assays $\vec{\varphi}$ was $8.6 \%$. The coefficient of variation within-batch ranged from $14 \%$ in the hypothyroid group to $3 \%$ in the euthyroid group. Very similar figures were calculated for the alcoholic extraction assay with the exception that ethanol tended to depress the binding in the low dose region of the standard curve (intercept $1 / \mathrm{B}$ was $1.887 \pm 0.092, \mathrm{n}=10$ ). A direct result of this effect was a reduction in the assay sensitivity (smallest detectable dose $11 \pm 6 \mathrm{fmol}$ ).

\section{NORMAL RANGE}

The normal range (mean $\pm 2 \mathrm{SD}$ ) of serum $\mathrm{T}_{3}$ in 53 euthyroid outpatients was $1.92 \pm 0.77 \mathrm{nmol} / \mathrm{l}$ $(1.25 \pm 0.50 \mu \mathrm{g} / \mathrm{l})$. This agrees well with values found by most other investigators using radio-

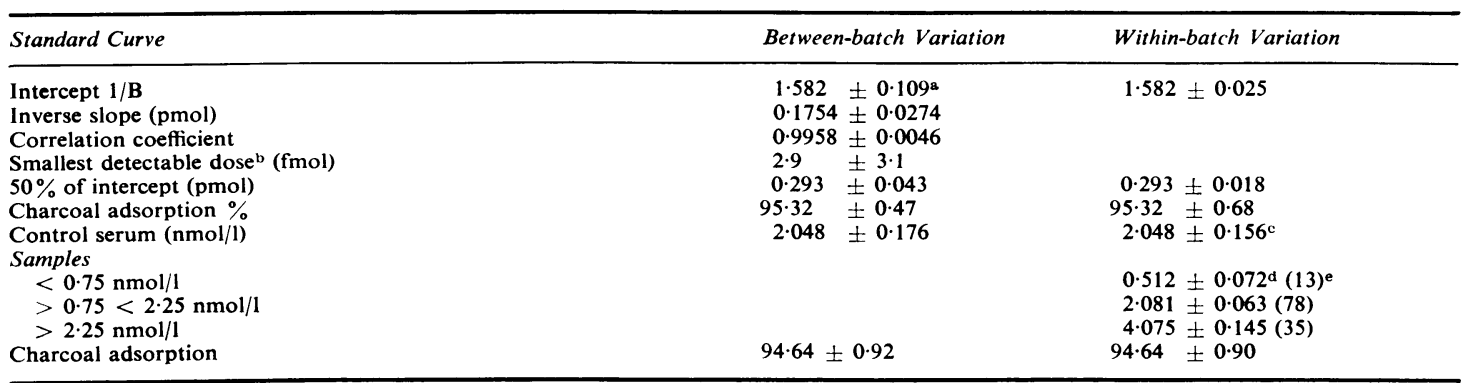

Table I Summary of radioimmunoassay characteristics

a Calculated from unweighted regression analysis, mean $\pm \mathrm{SD}$ bSD of zero dose/slope at this point $\times \sqrt{ } 2$ (Ekins et al, 1968) c Control serum at beginning and end of each run dCalculated by the duplicates method (Snedecor and Cochran, 1956) e Number of duplicates. 


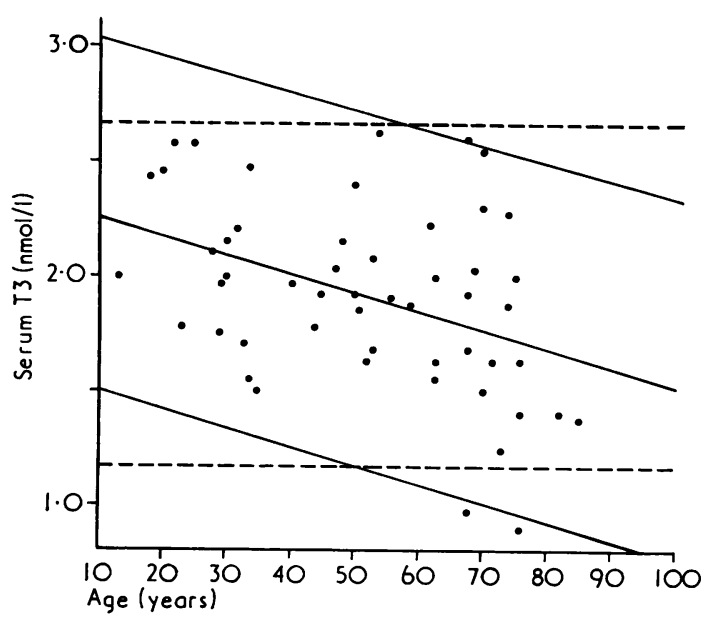

Figure A significant inverse correlation was observed between serum $T_{3}$ levels and age: $y=2 \cdot 34-0.0081 x$ ( $n=53, r=0.393, \mathrm{P}<0.01)$. The 95\% confidence limits for the regression equation are shown by the solid lines. The dashed lines delineate the $95 \%$ confidence limits for the pooled data.

immunoassay but different TGB blocking agents. A small but consistent fall in serum $\mathrm{T}_{3}$ with increasing age was observed in the present study (figure) and confirms the earlier observations of Brunelle and Bohuon (1972) and Rubenstein et al (1973).

\section{CLINICAL RESULTS}

Summarized in table II are the serum $T_{3}$ and $T_{4}$ levels in 117 unselected patients for whom in vitro thyroid function tests were requested. The biochemical data were compared with the retrospective assessment of a patient's thyroid status, and the final assessment was based on the outcome of examination, consultant opinion, and all investigations.

The salient features are as follows. All 38 hyperthyroid patients had high serum $\mathbf{T}_{3}$ concentrations although increased serum levels of thyroxine were observed in only 31 patients. Of the remainder with normal serum $\mathbf{T}_{4}$ concentrations, four were clinically diagnosed as 'early' thyrotoxicosis, one as 'recurrent' thyrotoxicosis while two were initially correctly diagnosed as ' $\mathrm{T}_{3}$-toxicosis'. Four of the five neomercazole-treated thyrotoxics had increased serum $T_{3}$ levels but normal or low serum $T_{4}$ concentrations. Low serum levels of $T_{3}$ and $T_{4}$ were observed in all seven cases of overt myxoedema. One patient had a border-line low serum $\mathrm{T}_{4}$ level but a normal serum $T_{3}$ concentration. The serum FTI was normal and the initial clinical diagnosis of hypothyroidism not supported. Low serum $\mathrm{T}_{3}$ levels were found in all five patients with hypoproteinaemia from various causes. However, serum $\mathrm{T}_{4}$ levels and the free thyroxine index were normal in every case. Two subjects, who admitted taking heroin, had raised serum $\mathrm{T}_{3}$ concentrations $(3.4$ and $3.6 \mathrm{nmol} / \mathrm{l})$ but normal serum $\mathrm{T}_{4}$ levels (122 and $\left.133 \mathrm{nmol} / \mathrm{l}\right)$ and normal FTI (7.5 and 8.4).

\section{Discussion}

A radioimmunoassay for the direct measurement of $T_{3}$ in serum has been described and its performance compared with an alcoholic extraction assay. For routine use the direct assay was preferred, primarily because the time for antibody incubation could be reduced to one hour at $37^{\circ} \mathrm{C}$ and fewer pipetting steps were involved. Thus results could be obtained on the same working day with fewer potential sources

\begin{tabular}{|c|c|c|c|c|c|c|c|}
\hline \multicolumn{2}{|l|}{ Final Assessment } & \multicolumn{3}{|l|}{$T_{3}$} & \multicolumn{3}{|l|}{$T_{4}$} \\
\hline & & Low & Normal & $H i g h^{\mathrm{b}}$ & Low & Normal & High $^{\mathrm{b}}$ \\
\hline $\begin{array}{l}\text { Hypothyroid } \\
\text { Hypoproteinaemic } \\
\text { T,-treated hypothyroids } \\
\text { Euthyroid } \\
\text { Pregnant euthyroid } \\
\text { Clinically euthyroid heroin users } \\
\text { Hyperthyroid } \\
\text { Neomercazole treated hyperthyroid } \\
\text { Thyroidectomized hyperthyroid on } \mathrm{T}_{\text {\& }} \text { replacement }\end{array}$ & $\begin{array}{l}(8)^{c} \\
(5) \\
(2) \\
(53) \\
(3) \\
(2) \\
(38) \\
(5) \\
(1)\end{array}$ & $\begin{array}{l}7 \mathbf{d} \\
5 \\
0 \\
2 \\
0 \\
0 \\
0 \\
0 \\
0\end{array}$ & $\begin{array}{r}1 \mathbf{e} \\
\mathbf{0} \\
\mathbf{1} \\
51 \\
0 \\
0 \\
0 \\
1 \\
0\end{array}$ & $\begin{array}{r}0 \\
0 \\
1 \\
0 \\
3 \\
2 \\
38 \\
4 \\
1\end{array}$ & $\begin{array}{l}7 \\
0 \\
0 \\
0 \\
0 \\
0 \\
0 \\
2 \\
0\end{array}$ & $\begin{array}{c}\mathbf{1}^{\mathbf{e}} \\
\mathbf{5} \\
\mathbf{0} \\
\mathbf{5 1} \\
\mathbf{0} \\
\mathbf{2} \\
\mathbf{7} \\
\mathbf{3} \\
\mathbf{0}\end{array}$ & $\begin{array}{r}0 \\
0 \\
2 \\
2 \\
3 \\
0 \\
31 \\
0 \\
1\end{array}$ \\
\hline
\end{tabular}

Table II Serum $T_{3}$ and $T_{4}$ levels in 117 patients for whom thyroid function tests were required

'Less than 2SD below the mean. Normal range for $T_{4}$ is 73 to $163 \mathrm{nmol} / 1$

bGreater than 2SD above the mean

cTotal number of cases in each group

dNumber of cases in each subgroup

eSame patient. 
of error. In terms of accuracy the direct assay overestimated the $T_{3}$ content on average by some $5 \%$. This value agrees well with the $95 \%$ efficacy of Merthiolate in displacing $T_{3}$ from TBG binding sites reported by Hüfner and Hesch (1973a) and Kirkegaard et al (1974).

A disturbing feature of the radioimmunological measurement of $T_{3}$ in unextracted serum is the occurrence of low values in patients with hypoproteinaemia as a result of nephrotic syndrome, coeliac disease or senile malabsorption. Low serum $T_{3}$ levels have also been detected in kwashiorkor. However, in the latter case this observation appears to be due to a methodological artefact, since no low $T_{3}$ values were observed when sufficient $T_{3}$-free normal serum was added to the immunoassay tube to make the serum protein level comparable to normal serum samples (van der Westhuyzen, 1973). Thus before any reliance can be placed on serum $T_{3}$ data from hypoproteinaemic patients it is essential that the immunoassay system be shown to be unaffected by large changes in serum protein levels. Further work is needed to elucidate this phenomenon. However, normal patient to patient variation in total serum protein content does not appear to affect the accuracy of the method significantly, and in practice it is the high serum $\mathbf{T}_{3}$ values that are of clinical importance.

Published ranges for euthyroid levels of serum $\mathbf{T}_{3}$ as determined by radioimmunoassay vary considerably, although workers have agreed that the mean lies between 1.5 and $2.3 \mathrm{nmol} / 1$ with a standard deviation of some 0.3 to $0.5 \mathrm{nmol} / 1$. This interlaboratory variation could be due to methodological differences since the apparent serum $T_{3}$ concentration depends to some extent upon the blocking agent used (Hüfner and Hesch, 1973a), but diet and age of the control group may also be important. Provided that the correct normal ranges are established for each area laboratory, small dietary differences should not affect clinical conclusions based on the radioimmunoassay data. However, the age distribution of the population studied might do so.

If the normal population confidence limits derived from a least squares regression analysis of serum $T_{3}$ level on patient's age are compared with those of the pooled data then areas can be identified where younger patients may be misclassified as early thyrotoxicosis and older patients wrongly considered to be euthyroid (figure). However, more data are required before the diagnostic value of this refinement of the normal range can be assessed. No agedependent changes in serum $T_{4}$ concentration were observed in the present study. In a much larger group of euthyroid patients, a small but significant decrease in serum $T_{4}$ levels was observed in patients over
65 years of age (Herrmann et al, 1974). The authors concluded that reduced protein-binding of thyroid hormones, particularly $T_{3}$, could be excluded as the $\vec{\Rightarrow}$

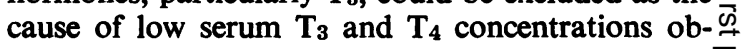
served in aged patients.

At the present time the usefulness of serum $T_{3} \frac{\overline{ }}{\bar{N}}$ measurements in the routine diagnosis of thyroid $\frac{\bar{\sigma}}{\sigma}$ disease is restricted to two well-defined areas. Where $\stackrel{\mathbb{}}{\complement}$

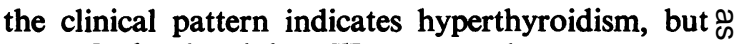
serum $\mathrm{T}_{4}$ level and the FTI are normal, measurement $\vec{\circ}$ of serum $T_{3}$ concentrations can confirm ' $T_{3}$-toxicosis', and seven such patients were identified in the $\vec{\omega}$ present series. Of these seven patients, four were $\stackrel{?}{=}$ diagnosed as 'early thyrotoxicosis'. The ability to $\frac{8}{8}$ provide biochemical support for this diagnosis is of great value and suggests that all patients for whom $v$ serum $\mathrm{T}_{4}$ estimations have been requested should ${ }^{\circ}$ also be screened for serum $T_{3}$. An increased serum $\vec{N}$ $T_{3}$ level relative to the $T_{4}$ concentration has been $ᄋ$ observed during treatment of hyperthyroidism (Bellabarba and Tremblay, 1972) and this occurred $\subseteq$ in four patients in the present study. In these cases $₹$ measurement of serum $T_{3}$ levels helps to define $\vec{\varphi}$ thyroid status.

Not all cases of increased serum levels of $\mathbf{T}_{\mathbf{3}}$, however, appear to be associated with clinical evidence of hyperthyroidism. In this study two clinically euthyroid heroin addicts had high levels of serum $T_{3}$ but normal $T_{4}$ concentrations. Whether this $\frac{\circ}{D}$ reflects the pituitary-thyroid relationship seen in $\stackrel{\varrho}{\Rightarrow}$ Pendred's syndrome (deafness and non-iodinedeficiency goitre) is not known, but Gomez-Pan et al (1974) recently reported such a patient with raised serum $T_{3}$ concentrations and normal levels of serum $\mathrm{T}_{4}$. Interestingly an increased TSH response to thyro- $\frac{}{0}$ tropin releasing hormone (TRH) was observed in this patient. Studies in mice have shown that codeine, which has a chemical structure very 8 similar to that of heroin, enhances the TSH response $₹$ to TRH (Redding et al, 1966). While caution must $\frac{\text { o }}{2}$ be exercised in drawing inferences from animal studies and applying them to the human it remains a possibility that heroin was having a similar effect in the patients addicted to this drug. However, in a or series of clinically euthyroid heroin addicts studied $N$ by Webster et al (1973) an increased mean serum $T_{4} \underset{\omega}{N}$ level was observed as a result of an elevated serum 0 TBG binding capacity. Serum $T_{3}$ levels were not measured.

In conclusion, a preliminary clinical evaluation of $\stackrel{\oplus}{+}$ serum $\mathbf{T}_{3}$ estimations in routine diagnostic use sug- $D$ gests that measurement of serum $\mathrm{T}_{3}$ levels would provide more information than $T_{4}$ and should be requested in all cases of suspected hyperthyroidism and in patients undergoing therapy for thyroid disorders. 


\section{References}

Bellabarba, D. and Tremblay, R. (1972). Serum pattern of thyroxine $\left(T_{4}\right)$ and triiodothyronine $\left(T_{3}\right)$ after treatment of thyrotoxicosis with antithyroid drugs. Int. J. clin. Pharmacol., 6, 18-21.

Bellabarba, D. and Tremblay, D. (1973). Effect of sodium ethylmercurithiosalicylate (Thiomersal) on serum binding of thyroid hormones. Canad. J. Physiol. Pharmacol., 41, 156-159.

Brunelle, P. and Bohuon, C. (1972). Baisse de la triiodothyronine sérique avec l'âge. Clin. chem. Acta, 42, 201-203.

Chopra, I. J., Solomon, D. H., and Beall, G. N. (1971). Radioimmunoassay for measurement of triiodothyronine in human serum. J. clin. Invest., 50, 2033-2041.

Ekins, R. P., Newman, G B., and O'Riordan, J. L. H. (1968). Theoretical aspects of 'saturation' and radioimmunoassay. In Radioisotopes in Medicine, In Vitro Studies, edited by R. L. Hayes, F. A. Goswitz, and B. E. P. Murphy, pp. 100. USAEC, Oak Ridge, Tennessee.

Gemmill, C. L. (1955). The apparent ionisation constants of the phenolic hydroxyl groups of thyroxine and related compounds. Arch. Biochem., 54, 359-367.

Gharib, H., Mayberry, W. E., and Ryan, R. J. (1970). Radioimmunoassay for triiodothyronine: a preliminary report. J. clin. Endocr., 31, 709-712.

Gomez-Pan, A., Evered, D. C., and Hall, R. (1974). Pituitarythyroid function in Pendred's syndrome. Brit. med. J., 2, 152-153.

Herrmann, J., Rusche, H. J., Kröll, H. J., Hilger, P., and Krüskemper, H. L. (1974). Free triiodothyronine $\left(\mathrm{T}_{3}\right)$ and thyroxine $\left(\mathrm{T}_{4}\right)$ serum levels in old age. Horm. metab. Res., 6, 239-240.

Hollander, C. S., Nihei, N., Mitsuma, T., Scovill, C., and Gershengorn, M. C. (1971a). Elevated serum triiodothyronine in association with altered available iodide in normal (NL) and hyperthyroid subjects. Clin. Res., 19, 560.

Hollander, C. S., Shenkman, L., Mitsuma, T., Blum, M., Kastin, A. J., and Anderson, D. G. (1971b). Hypertriiodothyroninaemia as a preliminary manifestation of thyrotoxicosis. Lancet, $2,731-732$.

Hüfner, M. and Hesch, R. D. (1973a). A comparison of different compounds for TBG-blocking used in radioimmunoassay for triiodothyronine. Clin. chim. Acta, 44, 101-107.

Hüfner, M. and Hesch, R. D. (1973b). Radioimmunoassay for triiodothyronine in human serum. Acta endocr. (Kbh.), 72, 464-474.

Kanagasabapathy, A. S. and Wellby, M. L. (1974). The use of merthiolate for TBG-blocking in the radioimmunoassay of triiodothyronine. Clin. chim. Acta, 55, 267-271.

Kirkegaard, C., Friis, T., and Siersbaek-Nielsen, K. (1974). Measurements of serum triiodothyronine by radioimmunoassay. Acta endocr. (Kbh.), 77, 71-81.

Larsen, P. R. (1971). Inhibition of triiodothyronine $\left(T_{3}\right)$ binding to thyroxine-binding globulin by sodium salicylate and its application to immunoassay of $T_{3}$ in human serum. Metabolism, 20, 976-980.

Lieblich, J. and Utiger, R. D. (1972). Triiodothyronine radioimmunoassay. J. clin. Invest., 51, 157-166.

Mitsuma, T., Colucci, J., Shenkman, L., and Hollander, C. S. (1972). Rapid simultaneous radioimmunoassay for triiodothyronine and thyroxine in unextracted serum. Biochem. biophys. Res. Commun., 46, 2107-2113.

Mitsuma, T., Gershengorn, M. C., Colucci, J., and Hollander, C. S. (1971). Radioimmunoassay of triiodothyronine in unextracted human serum. J. clin. Endocr., 33, 364-367.

Patel, Y. C. and Burger, H. G. (1973). A simplified radioimmunoassay for triiodothyronine. J. clin. Endocr., 36, 187-190.

Redding, T. W., Bowers, C. Y., and Schally, A. V. (1966). An in vivo assay for thyrotropin releasing factor. Endocrinology, 79, 229-236.

Rubenstein, H. A., Butler, V. P., Jr., and Werner, S. C. (1973). Progressive decrease in serum triiodothyronine concentrations with human aging: radioimmunoassay following extraction of serum. J. clin. Endocr., 37, 247-253.

Snedecor, G. W. and Cochran, W. G. (1956). Statistical Methods, 5th edition. Iowa State University Press, Ames, Iowa.

Sterling, K., Refetoff, S., and Selenkow, H. A. (1970). $T_{3}$ thyrotoxicosis: thyrotoxicosis due to elevated serum triiodothyronine levels. J. Amer. med. Ass., 213, 571-575.

Van der Westhuyzen, J. M. (1973). Plasma-T 3 assay in kwashiorkor. (Letter). Lancet, 2, 965.

Watson, D. and Lees, S. (1973). Comparative study of thyroxine assays employing kit radio-ligand reagents. Ann. clin. Biochem., 10, 14-22.

Webster, J. B., Coupal, J. J., and Cushman, P., Jr. (1973). Increased serum thyroxine levels in euthyroid narcotic addicts. J. clin. Endocr., 37, 928-934. 